\title{
FDI Versus Economic Growth: An Empirical Investigation for Causality
}

\author{
Safaeduzzaman Khan \\ Department of Economics, University of Barisal, Barisal, Bangladesh
}

\begin{abstract}
This paper attempts at finding the long run relationship and causality between foreign direct investment and economic growth for Bangladesh using time series data over the 1974-2009 period. For empirical testing, we execute three standard econometric tools: Augmented Dickey Fulller (ADF) test for unit root detection, Granger causality test and Testing for Akaike Information Criteria (AIC) and Bayesian-Schwartz Information Criteria (BIC). This study finds that FDI and GDP was not cointegrated. Moreover, using Granger Causality test it is shown that the FDI and openness are not significantly causing the GDP per capital both in the short and long run. The regression result indicates that FDI is positively correlated to the economic growth of Bangladesh but it has not yet been established as a significant determining factor for the growth. The study suggests adopting appropriate steps so that FDI can be used as a contributing factor to the economic development.
\end{abstract}

Keywords: FDI, economic development, Granger causality, cointegration.

DOI: $10.7176 / \mathrm{JESD} / 10-16-18$

Publication date: August $31^{\text {st }} 2019$

\section{Introduction}

Over the years it is acknowledged by many development experts across the countries that one of the most feasible ways of poverty reduction is to achieve and sustain higher economic growth rate with some level of equity. Day by day, countries are becoming more and more integrated and opened to free trade due to globalization. Hence countries are implementing liberal economic policies and such liberal policies, especially in LDCs, are encouraging huge capital inflows from first world countries. Over the last decades, the remarkable increase in FDI inflows to developing countries demand an analysis of the impact of FDI on economic growth.

Apparently, it may seem that FDI will foster economic growth because of many reasons. Firstly, it will bring the technological improvement in the host country and this technology will be transferred into the other sectors of the domestic economy which will foster the export and thus development. Secondly, for the import substitution firms, it will enhance competition and thus will increase efficiency and productivity. Thirdly, it will create the employment opportunity for the host country which will increase the GDP directly through factor income and indirectly through multiplier effect. However, the opposite arguments are also not uncommon. Firstly, it may reduce the savings (Razzaque and Ahmed, 2000) and thus less domestic investment which may result in reduction in growth. Secondly, it may crowd out domestic investment which may result into reduction in the economic growth.

The issue on the ground that FDI enhances economic growth does not have a unanimous support. A positive effect of FDI and trade on economic growth may simply reflect the fact that FDI is attracted to countries that are expected to grow faster and follow open-trade policies. The interrelationship among FDI, trade, and economic growth is therefore, important to examine. It should be pointed out that the direction of causation may run either way. As theory is not clear, this issue has been the subject of empirical studies. Hence, the study on FDI is imperative to reach in any conclusion.

The present study is a modest attempt to examine the empirical relationship between FDI and economic growth in Bangladesh from 1974 to 2009. The main focus of this study lies in analyzing the behavior of some selected macroeconomic indicators accompanying the surge in inflows of foreign direct investment into Bangladesh since 1976 the year in which the inflows started entering on a significant scale. The econometric methodology used in this study is time series analyses, with bi-variate time-series regression, Granger causality test, Augmented Dickey Fuller (ADF) test and OLS method. These techniques allow us to capture the short-term and long-term effects of FDI inflows. Data on the relevant variables from 1974 to 2009 is used.

\section{Literature Review}

The rapid growth of FDI and its overall magnitude had sparked numerous studies about the issue whether FDI really fuel up the economic growth. Some of the major studies are reviewed and discussed below. Khawar (2005) examines the impact of contemporaneous foreign direct investment on growth in the period 1970-92 using the method of ordinary least squares (OLS). The study found that foreign direct investment is significant and positively correlated with growth as well as domestic investment. The population growth rate, initial GDP and political instability variables were negatively correlated with growth, which is keeping with the findings in the empirical 
growth literature. The human capital measure was not significant in the analysis. Hansen and Rand (2005) analyses the casual relationship between FDI and GDP in a sample of 31 developing countries. Using estimators for heterogeneous panel data, they found a unidirectional causality between FDI to GDP ratio implying that FDI causes growth. Borensztein et al. (1998) find that FDI is more productive than domestic investment only when the host country has a minimum threshold stock of human capital. De Mello (1999) finds a positive impact for FDI on output growth regardless of the technological status of a host country as a technological leader. Dritsaki, et al. (2004) investigates the relationship between trade, FDI and economic growth for Greece over the period 19602002. The cointegration analysis suggests that there is a long run equilibrium relationship. They also use the granger causality test and the results show that there is a casual relationship between the variables. Similar type of study regarding the relationship between FDI and economic growth for Cyprus, 1976-2002 is examined by Feridun (2004) using the methodology of granger causality and strong evidence emerges that the economic growth as measured by GDP in Cyprus is Granger caused by the FDI, but not vice versa. Chowdhury and Mavrotas (2003) examine the casual relationship between FDI and economic growth for Chile, Malaysia and Thailand using time series data covering the period 1969-2000 and their empirical findings clearly suggest that GDP causes FDI in the case of Chile and not vice-versa, while for both Malaysia and Thailand, there is a strong evidence of a bi-directional causality between the two variables. Lensink and Marrissey (2001) estimate the standard model using cross section, panel data and instrumental variable techniques and find that FDI has a positive effect on growth whereas volatility of FDI has a negative impact. They also find that the evidence for a positive effect of FDI is not sensitive to which other explanatory variables are included, although the significance of the estimated coefficient does vary according to the specification. Using the methodology of Granger Causality and Vector Auto Regression (VAR), the study done by Feridunm (2004) examined the relationship between Foreign Direct Investment and GDP per capita in the economy of Cyprus. Strong evidence suggested that the economic growth as measured by GDP in Cyprus was caused (Granger causality) by the FDI, but not vice- versa. Results further suggested that Cyprus's capacity to progress on economic development will depend on the country's performance in attracting foreign capital. Bornsztein, Gregorio and Lee (1998) have argued that FDI had a positive growth effect when the country had a highly educated workforce that allowed it to exploit FDI spillovers. However, Alfaro et al (2003) found that FDI promotes economic growth in economies with sufficiently developed financial markets.

\section{Data Collection and Description of Variables}

The relationship between FDI and economic growth is examined using data from Bangladesh over the period from 1974 to 2009 . Secondary data for this study are collected from the Country Meta DatabaseBangladesh from the World Bank Website "Data" tab. The following is a description on the variable we have used in this study, and the way data has been constructed for each variable:

1. Foreign Direct Investment (FDI) inflows are net inflows of investment to acquire a lasting management interest in an enterprise operating in an economy other than the home country of the investor. The measure is the sum of equity capital, reinvestment of earnings, other long-term, and short-term capital as shown in the balance of payments. No private portfolio investment is considered in this study.

2. Gross Domestic Product (GDP) in current market price and per capita GDP data have been collected from various publications of World Bank, UNCTAD, and IMF. The data on annual growth rate of GDP is from World Bank Publications. We denote the GDP growth rate as GDPG.

3. Gross fixed capital formation (GFCF) constitutes investment is made on the GFC. So, we observe the contribution of GFCF to economic growth with other variable. Formally, saving has not been considered because $\mathrm{S} \neq \mathrm{I}$, some portion has been invested and other portion has been consumed.

4. Dummy variable (DM) $[\mathrm{D}=1$ for democratic government, $\mathrm{D}=0$ for otherwise $]$. It is introduced primarily in the model to capture the effect of good governance in affecting the FDI a dummy variable is used. Good governance is proxied by democratic government.

The following regression model is specified to measure the effects of FDI on economic growth. We estimate the effects of FDI on economic growth by ordinary least squares (OLS) method. The model specification will be

$$
\mathrm{GDPG}=\alpha_{0}+\beta_{1}(\mathrm{FDI})+\beta_{2}(\mathrm{GFCF})+\mathrm{D}_{\mathrm{m}}+\varepsilon
$$

\section{Computation and Data Analysis}

4.1 Regression Results

This section includes a series of regressions to underscore the many advantages and growth prospects that FDI inflows have brought to the Bangladeshi economy. The methodology of the empirics constitutes a series of regressions using the Ordinary Least Squares (OLS) model to prove a significant correlation between FDI and economic growth. Here, the model specification takes the form:

$$
\mathrm{GDPG}=\alpha_{0}+\beta_{1}(\mathrm{FDI})+\varepsilon
$$

The data used in the analysis will begin from 1974 when FDI had just begun to flow into the nation after the era of reconstruction and war recovery. The tables express the coefficients and t-statistics of each independent $\mathrm{x}$ - 
variable to demonstrate its level of significance. The R-squared or coefficient of determination is included to represent how much variation in the dependent $y$-variable is captured by the regression. To find out the individual influence of FDI on GDP and other variables firstly we have considered bi-variate regression analysis The bi-variate regression results of the economic growth of Bangladesh based on FDI is presented in table 1.

Table-1: Bi-variate Regression Results

Independent Variable: Foreign Direct Investment (FDI)

\begin{tabular}{|c|c|}
\hline Explanations & Measures \\
\hline Dependent Variable & GDP $(\mathrm{mn} \$)$ \\
\hline Constant coefficient & 2750 \\
\hline Co-efficient & 63.285 \\
& $(8.15)^{* * *}$ \\
\hline $\mathrm{R}^{2}$ & 0.668 \\
\hline Standard Error (Se) & 7.769 \\
\hline $\mathrm{R}^{2}$-Adjusted & 0.658 \\
\hline Df & 34 \\
\hline
\end{tabular}

Absolute value of t-statistics in parentheses

* Significant at $10 \%$; ** Significant at 5\%;*** Significant at $1 \%$.

The regression shows that a $\$ 1$ million increase in FDI inflows raises GDP by US\$ 63.29 million. Although the coefficient is subject to standard error 7.769 , it is statistically significant at $1 \%$ level. Table 1 focuses a good influence of FDI inflows on GDP growth rate of Bangladesh. The regression result specifies that there is no change in the independent variable, the GDP growth rate of Bangladesh remains 3.96 percent with standard error 1.872. In general way, without testing any statistical significance, the above discussion reveals that FDI inflows influence the growth of GDP and also per capita GDP growth. But we are getting apparently a good relation between FDI/GDP growths by a two variable regression. However, we have used time series data for the study. All macroeconomic time series data show some trend. When working with the time series data, the first issue is whether the series are stationary or not. Without following the standard methods for test the statistical significance of the variables or estimator the resulting outcome will be of no practical use. Here is our analysis of the estimation using econometric issues.

\subsection{Causal Impact of FDI on GDPG}

Our objective of the study is to find out the relationship between FDI and economic growth in individual country like Bangladesh. The interest is to show the impact of FDI on economic growth, and GDP growth has taken as a general measure of economic growth of an economy.

Table-2: Correlation Matrix (Bangladesh)

\begin{tabular}{|c|c|c|c|}
\hline Variables & GDPG & FDI & GFCF \\
\hline GDPG & 1 & 0.3 & 0.33 \\
\hline FDI & 0.3 & 1 & 0.61 \\
\hline GFCF & 0.33 & 0.61 & 1 \\
\hline
\end{tabular}

Note: The correlation matrix indicates that we can use GDPG, FDI, GFCF as our key variables because they do not share multi-colinearity. As we want to see the rate of change of these variables we used log linear function.

The empirical model is estimated by OLS method. However, before estimation it is imperative to check the time series properties of the underlying data. A stochastic process is said to be stationary if its mean and variance are constant over time and the covariance between the two time periods depends only on the distance between the two time periods and not the actual time at which the covariance is computed. If the variables are not integrated to the same order, then the regression may be spurious one and the resulting outcome will be of no practical use. To avoid this problem, before estimating the model, unit root test is carried out.

\subsection{Augmented Dickey Fuller $(A D F)$ test for Unit Root Detection}

Unit root test is a prerequisite of testing long run relationship between two or more time series data. Augmented Dickey-Fuller (DF) and Phillips-Perron (PP) tests are widely used in empirical research. To test the stationarity of the variables we conducted the Augmented Dickey-Fuller test for all variables. The criterion is if the absolute value of the test statistics of the Augmented Dickey-Fuller test is higher than the critical absolute value, the null hypothesis is rejected. It means that there is no unit root in the series and the variables are stationary. Conversely if the absolute value of the test statistic is less than the critical absolute value, the null hypothesis is not rejected. Using Stata software package the results of the Augmented Dickey-Fuller test are presented in table 3.

From the Table-3 it is found that all variables contain unit root. To make the variables stationary the first difference of all variables were taken and found that the variables were integrated of order one i.e. I (1). The results show that LnGDPG, LnFDI, LnGFGC are level non-stationary at $1 \%, 5 \%$, and $10 \%$ levels, but first difference 
stationary. However, LnFDI is also trend stationary at its level.

Table-3: ADF Unit Root Test Results (Bangladesh)

\begin{tabular}{|c|c|c|c|c|}
\hline \multirow{2}{*}{ Variables } & \multicolumn{2}{|c|}{ Level } & \multicolumn{2}{c|}{ First difference } \\
\cline { 2 - 5 } & Without Trend & With Trend & Without Trend & With Trend \\
\hline LnGDPG & 1.512 & -1.173 & $-8.374^{*}$ & $-11.62^{*}$ \\
\hline LnFDI & -0.094 & $-4.033^{*}$ & $-7.011^{*}$ & $-7.390^{*}$ \\
\hline LnGFGC & -0.758 & -2.786 & $-6.760^{*}$ & $-7.507^{*}$ \\
\hline Dm & -0.969 & -2.00 & $-5.656^{*}$ & $-5.561^{*}$ \\
\hline
\end{tabular}

Critical values for $1 \%, 5 \%$ and $10 \%$ significance levels are $-2.6369,-1.9513$ and -1.6107 respectively. Critical values for $1 \%, 5 \%$ and $10 \%$ significance levels are $-3.7700,-3.1900$ and -2.8900 respectively. $*, * *$, and $* * *$ indicate significance at $1 \%, 5 \%$ and $10 \%$ levels respectively.

Table-4: Multivariate Regression Results

\begin{tabular}{|c|c|c|c|c|}
\hline \multicolumn{3}{|c|}{ Dependent Variable: LnGDPG } & \\
\hline Variable & Coefficient & Std. Error & t-Statistic & Prob. \\
\hline C & 6.320 & 0.266 & 23.69 & 0.00 \\
\hline LnFDI & 0.003 & 0.003 & 0.897 & 0.37 \\
\hline LnGFCF & 0.451 & 0.034 & 13.26 & 0.00 \\
\hline DnM & 0.151 & 0.050 & 2.980 & 0.00 \\
\hline
\end{tabular}

R-squared-0.962, Adjusted R-squared-0.958, S.E. of regression-0.084, F-statistic-257.4, Prob(F-statistic)- 0.00

Durbin-Watson stat-0.670, Akaike info. Criterion (AIC)-2.00, Bayesia-Schwarz info. Criterion (BIC)- (-1.82)

From the above Table-4 it is seen that, except LNFDI, all other variables have statistically significant impact, with expected signs, on GDP growth. The highest impact comes from GFCF, which is quite obvious. The sign of LNFDI coefficient is positive but it is statistically insignificant. The result indicates that FDI is positively correlated to the economic growth of Bangladesh but it has not yet been established as a significant determining factor for the economic growth of Bangladesh. The coefficient of capital formation (GFCF) is significant at the $1 \%$ level and the sign is positive indicating that $1 \%$ increase in gross fixed capital will increase the growth rate of GDP by $13.266 \%$. This means that capital formation has more positive influence on economic growth in Bangladesh. The coefficient of dummy variable is positive and statistically significant. This implies that democratic governments have been contributing to the economic growth of Bangladesh. The reason may be democratic governments make effective policies and build good institutions which ultimately lead to economic growth. $\mathrm{R}^{2}$ and adjusted- $\mathrm{R}^{2}$ indicate that the behavior of foreign direct investment in Bangladesh is almost completely explained by the independent variables included in the model. F statistics shows that the independent variables are jointly highly significant. The coefficient of determination $\left(\mathrm{R}^{2}=0.96\right)$ is quite high and reveals almost a perfect fit of the model. This indicates the proportion of total variation in GDP growth explained by the explanatory variables.

\subsection{Granger Causality Test}

The Granger-causality test is used to ascertain the direction of causality between GDPGR and FDI. This test assumes that the underlying time series are stationary, i.e., $\mathrm{I}(0)$ processes. Therefore, it is imperative to examine whether GDPGR and FDI are stationary. Augmented Dickey-Fuller (ADF) test is employed to check the stationary property of these two variables. One of the implications of Granger- causality test is that if two variables, say X, and $\mathrm{Y}$, are cointegrated and each is individually $\mathrm{I}(\mathrm{I})$, that is, integrated of order one, then either $\mathrm{X}$, must Grangercause Y, or Y, must Granger-cause X, Therefore, it is necessary to ascertain whether two variables X, and Y, are cointegrated, that is, whether there is any long-run relationship between these two variables.

The casual relationship between GDPGR and FDI is examined by standard Granger-causality test. Following equations are estimated for this purpose:

$$
\begin{aligned}
& \mathrm{GDPG}_{\mathrm{t}}=\sum_{i=1}^{n} a_{i} G D P G_{t-i}+\sum_{j=1}^{m} b_{j} F D I_{t-j}+u_{1 \mathrm{t}} \\
& \mathrm{FDI}_{\mathrm{t}}=\sum_{i=1}^{n} c_{i} G D P G_{t-i}+\sum_{j=1}^{m} d_{j} F D I_{t-j}+\underline{u}_{2 \mathrm{t}}
\end{aligned}
$$

The rejection of null hypothesis that FDI does not Granger-cause GDPG requires that (a) estimated coefficients on the lagged FDI in (1) are statistically different from zero (i.e., $\sum b j \neq 0$ ) and (b) the set of estimated coefficient on the lagged GDPG in (2) is not statistically different from zero (i.e., $\sum \mathrm{cj} \neq 0$ ). Similarly rejection of null hypothesis that GDPG does not Granger-cause FDI requires that (a) the estimated coefficients on the lagged 
FDI in (1) are not statistically different from zero (i.e., $\sum b j \neq 0$ ) and the set of estimated coefficient on the lagged GDPG in (2) is not statistically different from zero (i.e., $\sum$ cj $\neq 0$ ).

As Granger- causality test is very sensitive to the number of lags used in estimation procedure, optimum lag length is determined by applying Schwarz Criterion (SC). According to this criterion optimum lag length $\mathrm{m}$ is obtained by minimizing the function.

$$
\mathrm{SC}=\ln a^{`} 2+\operatorname{mlnn}
$$

Where, $a^{\prime} 2$ is the maximum likelihood estimate of a2 (RSS/n).

The results of Granger-causality tests are reported in Table-5. The Schwartz Information Criterion (SC) has been used to determine the optimal lag length in the test.

The results reported in Table-5 show that null hypothesis that FDI does not Granger-cause GDPGR is not rejected because the F statistics yields a value of 0.33376 which is below the critical value of $\mathrm{F} 0.01=5.53$. Thus, we can not reject the null hypothesis $(\mathrm{bj}=0)$. This signals that FDI does not Granger causes growth in Bangladesh. On the other hand the next portion of the results in the table indicates that GDP growth Granger causes FDI in Bangladesh ( F statistics 5.5776, which exceeds the critical value of F0.01 = 5.53).

Table-5: Granger-Causality Test

\begin{tabular}{|c|c|c|c|}
\hline Null Hypothesis: & $\mathrm{m}$ & F-Statistic & Probability \\
\hline LnFDI does not Granger Cause LnGDP & 2 & 0.333 & 0.719 \\
\hline LnGDP does not Granger Cause LnFDI & 2 & 5.577 & $0.009^{*}$ \\
\hline
\end{tabular}

(Causality test indicates that there is a unidirectional causality from GDP to FDI in case of Bangladesh).

Notes: * Indicates the $\mathrm{t}$ values are significant at 1 percent level, Optimum lag lengths $(\mathrm{m})$ are determined by minimizing the Akaike Information criteria (AIC) by Stata package.

The result also confirms that there is no bi-directional causality (feedback) between GDPGR and FDI. That is, Causality test indicates that there is a unidirectional causality from GDP to FDI in case of Bangladesh. So, the conclusion is that, in Bangladesh, there is a long-run equilibrium relationship between economic growth and FDI; and economic growth Granger-causes FDI.

\section{Findings}

The main objective of our study was to analyze the relationship between FDI and economic growth in Bangladesh. From the analysis of simple regression, it is evidence that there is a strong positive correlation between FDI and growth of GDP or growth of GDP per capita. However, to examine the impact of FDI on economic growth using multiple regression with time series data we got ambiguous results. The above empirical exercise does not find any significant role for FDI in the economic growth of Bangladesh. Moreover, the FDI inflows into Bangladesh is very low comparing to the other neighbor South Asian Countries. It is found that, FDI is positively correlated to the economic growth of Bangladesh but it has not yet been established as a significant determining factor for the economic growth of Bangladesh. The estimated coefficient for FDI is positive but statistically insignificant. When the coefficient is insignificant, no inference can be drawn from the result under the used data set and the model. It cannot be said that FDI has a positive or negative impact on economic growth. The result is ambiguous for Bangladesh.

\section{Limitations}

However, before taking any conclusion from this study as canonical one should consider the limitation of the study also. Firstly, the drastic simplicity of the model might have some effect on the result. Secondly, only one model of growth or production function was used and using other model could have some impact on the result that we reached.

\section{Conclusion}

Though, the finding of the study is that FDI has not been established as a significant determining factor for the economic growth of Bangladesh; it can easily be inferred that FDI policy should be formulated in such a way that causes attraction of more foreign potential direct investors and NRIs to invest in the country in those sectors which create employment and income in a larger scale. In brief, our findings suggest some policy insights. Firstly, only attracting the FDI cannot necessarily bring economic development and hence Government's all-out effort should not be only to attracting the FDI investments but also to ensure that this investment can be used in such a way that can contribute the economy positively. Secondly, even though FDI and openness are believed to be significant predictors of GDP but it not established by the data and so it is urgent for the government to pay attention to other factors which are necessary for supporting this variables working for the growth such increasing better and skilled workforce, creating supportive political environment etc. Thirdly, FDI as such cannot bring any positive outcome 
but the way it is invested and the sector in which this investment goes is also equally important.

\section{References}

Alam, M. S (1999) Foreign Direct Investment and Economic Growth of India and Bangladesh: A Comparative Study. The Indian Journal of Economics, Allahabad, Vol. LXXX, No. 316, pp. 1-14.

Alfaro, et al. (2003) "Foreign Direct Investment and Economic Growth: The Role of Local Financial Markets" Journal of International Economics, 61, pp 512-33.

Athukorala, P. and Menon, J (1995) Developing Countries with Foreign Investment: Malaysia. Australian Economic Review 1: pp. 9-22.

Balasubramanyam, V. N. and Mahambare, V (2003) FDI in India. Transnational Corporation, Vol. 12, No. 2, UNCTAD.

Barro, R (1991) Economic Growth in a Cross Section of Countries. Quarterly Journal of Economics, vol. 106, pp. 407-444.

Borensztein, E., De Gregorio, J., and Lee, J. W (1998) How Does Foreign Direct Investment Affect Growth?. Journal of International Economics, vol. 45, pp. 115-35.

Bosworth, B. and Collins, S (1999) Capital Flows to Developing Economies: Implications for Saving and Investment. Brookings Papers on Economic Activity:1.

Carkovic, M and Levine, R (2002) Does Foreign Direct Investment Accelerate Economic Growth?. University of Minnesota Working Paper, May, 2002.

Chakraborty, C. and Basu, P (2002) Foreign direct investment and growth in India: a cointegration approach. Applied Economics, Vol. 34, pp.1061-1073.

Chakraborty, C. and Nunnenkamp, P (2006) Economic Reforms, Foreign Direct Investment and its Economic Effects in India Kiel Working Paper No. 1272, The Kiel Institute for the World Economy, Germany.

Chakraborty, P. \& A. K. Mottalab (1998) Foreign Direct Investment: The Bangladesh Scenario. Development Review, Planning \& Development Academy, Dhaka. Vol.9/10, 1997 \& 1998.

Chary, S. Narasimha and V. Gangadhar (2006) Foreign Direct Investment: A Study of India and China. The Indian Journal of Commerce, Vol. 59, No. 4, pp. 52-61.

Chowdhury, A, Mavrotas, G (2003) Foreign Direct Investment and Growth: What Causes What?. Department of Economics, Marquette University, USA,World Institute Development Economic Research/United Nations University (UNU/WIDER).

De Mello, L. R (1997) Foreign Direct Investment in Developing Countries and Growth: A Selective Survey. The Journal of Development Studies, Vol 34, No. 1. pp. 1-34.

Dicky, D.A and W.A Fuller (1981) Likelihood Ratio Statistics for Autoregressive Time Series with a Unit Root. Econometrica, 49, July, pp. 1057-72.

Dutt, K. A (1997) The Pattern of Direct Foreign Investment and Economic Growth. World Development, Vol. 25, No. 11, pp. 1925-1936.

Enders, Walter (1995) Applied Econometric Time Series. New York: John Wiley \& Sons.

Granger, C. W. J (1981) Some Properties of Time-Series Data and Their Use in Econometric Model Specification. Journal of Econometrics 16.

Feridun, J. (2004). "Foreign Direct Investment and Economic Growth: A Causality Analysis for Cyprus, 19762002" Journal of Applied Sciences 4, no. 4, 654-657.

Flexner. N (2000) Foreign Direct Investment and Economic Growth in Bolivia, 1990-1998. Economic Policy Division, Central Bank of Bolivia.

Government of Bangladesh (GOB) Bangladesh Economic Review 2005.

Gregorio, De J (2003) The Role of Foreign Direct Investment and Natural Resources in Economic Development. Central Bank of Chile Working Paper No. 196.

Iqbal, Alam. B (2006) FDI: A Tool for Economic Development. Foreign Trade Review, Vol. XLI, No. 2, pp. 6279.

Jason-Lewis, J (1998) Factors Influencing Foreign Direct Investment in Lesser Developed Countries. The Park Place Economist, Vol. VIII.

Khan M. I (2009) Foreign Direct Investment in India and Bangladesh: A Comperative Study. Journal of Business Administration. IBA, Dhaka.

Khawar, M (2007)Foreign Direct Investment and Economic Growth: A Cross-Country Analysis. Global Economy Journal, Vol. 5, Issue 1, pp.1-10.

Lall, S., (1993) Foreign Direct Investment in South Asia. Asian Development Review, Vol.11, No.1, pp.102-119.

Lucas, R.E (1990) Why Does Capital Flows From Rich to Poor Countries. American Economic Review, Vol.80, pp, 92-96.

Mazumdar, T. (2005) Capital Flows into India: Implications for its Economic Growth. Economic Political Weekly. May. 
Nagesh, K., (1996) India: Industrialization, Liberalization and inward and outward foreign direct investment in J.H. Dunnig and Rajneesh Narula (ed), Foreign Direct Investment and Governments, New York, P. 348-378.

Nunnenkamp, Peter \& Spatz, Julius (2002) Determinants of FDI in developing countries: has globalization changed the rules of the game?. Translational Corporations, Vol. 11, No. 2.

Razzaque, A; N. Ahmed: "A Re-examination of Domestic Saving-Foreign Aid Relationship in the Context of Bangladesh" The Bangladesh Development Studies, XXVI 4, pp 1-37. (2000)

Sahoo, P., (2006) Foreign Direct Investment in South Asia: Policy, Trends, Impact and Determinants. $A D B$ Institute Discussion Paper No. 56, pp. 6. 